DOI: $\underline{10.7242 / 2658-705 X / 2020.1 .3}$

УДК 612.017:612.018

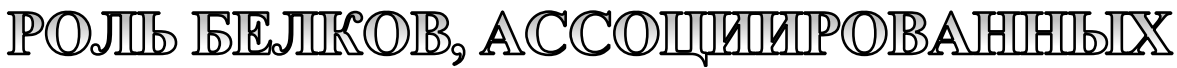

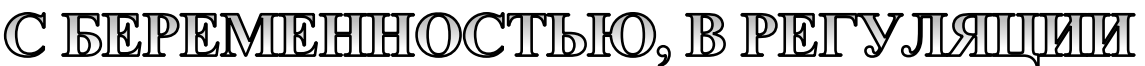

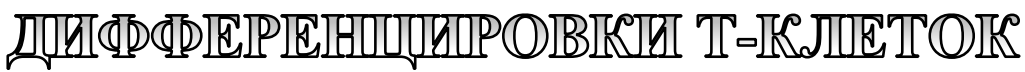

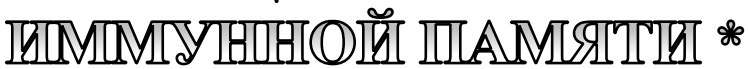

\begin{abstract}
С.А. Заморина, Институт экологии и генетики микроорганизмов УрО РАН
В.П. Тимганова, Институт экологии и генетики микроорганизмов УрО РАН

М.С. Бочкова, Институт экологии и генетики микроорганизмов УрО РАН

Л.С. Литвинова, Балтийский федеральный университет им. И. Канта

К.А. Юрова, Балтийский федеральный университет им. И. Канта

О.Г. Хазиахматова, Балтийский федеральный университет им. И. Канта

П.В. Храмцов, Институт экологии и генетики микроорганизмов УрО РАН; Балтийский федеральный университет им. И. Канта

С.В. Кочурова, Институт экологии и генетики микроорганизмов УрО РАН

М.Б. Раев, Институт экологии и генетики микроорганизмов УрО РАН
\end{abstract}

Изучена роль хорионического гонадотропина (ХГ), альфа-фретопротеина (АФП) и трофробластического $\beta$-1-гликопротеина (ТБГ) в регуляции процессов, определяющих диффреренцировку и созревание наивных Т-клетокпредшественниц в Т-клетки памяти. Установлено, что ХГ, АФП и ТБГ оказывают преимущественно угнетающий эффеект на экспрессию активационных маркеров CD28 и CD25 наивными (CD45RA ${ }^{+}$) Т-клетками и Т-клетками памяти (CD45R0 ${ }^{+}$), практически не влияя на экспрессию маркера пролиферации CD71. Установлено, что процессы диффреренцировки наивных Т-клеток и Т-клеток памяти под воздействием ХГ, АФП и ТБГ осуществляются за счет изменения экспрессии генов - U2af1/4, Gfi1 и hTERT, регулирующих альтернативный сплайсинг гена Ptprc (кодирующего молекулу CD45). Одновременно ХГ, АФП и ТБГ стимулировали аутокринную продукцию ИЛ-2 как наивными Т-клетками, так и Т-клетками памяти. Таким образом, впервые показаны модулирующие эффректы вышеназванных фетоплацентарных белков в отношении дифференцировки и функциональной активности Т-клеток иммунной памяти.

Ключевые слова: альфа-фетопротеин, хорионический гонадотропин, трофобластический b-1-гликопротеин, Т-клетки иммунной памяти, беременность, CD45.

\section{Введение}

Иммунологическая память - это способность иммунной системы отвечать бо- лее быстро и эффективно на антиген (патоген), с которым у организма был предварительный контакт. Таким образом, при

* Работа выполнена при финансовой поддержке РФФИ, проект 16-44-590049, программы повышения конкурентоспособности (5-100) и субсидии «Организация проведения научных исследований 20.4986.2017/ВУ» БФУ им. И. Канта. 
беременности важно соблюсти баланс между выбором - ответить на данный антиген, если он инфекционный, или не ответить на антиген, если он эмбриональный. Какие факторы регулируют этот выбор? Мы показали, что белки, ассоциированные с беременностью, принимают непосредственное участие в дифференцировке и созревании наивных Т-клеток памяти посредством регуляции альтернативного сплайсинга гена Ptprc, что, в конечном итоге, может определять исход беременности. Важно понимать, что состояние беременности можно охарактеризовать как иммунную толерантность (терпимость) к антигенам эмбриона, который является для материнского организма наполовину генетически чужеродным. Предполагается, что белки, ассоциированные с беременностью, целенаправленно модулируют иммунную систему матери таким образом, чтобы она нее испытывала «агрессивных чувств» по отношению к антигенам эмбриона, но эффективно справлялась с инфекционными агентами. Работа по проекту была посвящена изучению роли фетоплацентарных белков в установлении этого сложного баланса иммунных реакций на уровне Т-клеток иммунной памяти.

\section{Белки, ассоциированные с беременностью}

Относительно недавно методами протеомики продемонстрировано, что лишь несколько молекул из более чем 400, ассоциированных с беременностью, регулируют иммунную толерантность матери, среди них - трофобластический 1-гликопротеин (ТБГ), хорионический гонадотропин (ХГ) и альфа-фетопротеин (АФП) [13, 463-472].

Известно, что ХГ, являясь плацентарным аналогом лютеотропного гормона, в физиологических условиях продуцируется после оплодотворения клетками трофобласта. Гормон отличается широким спектром биологического действия, регулируя стероидогенез плаценты и плода, а также оказывая эффекты на уровне иммунной системы. Максимальная концентрация ХГ в период гестации ( $100 \mathrm{ME} /$ мл) совпадает с экспрессией антигенов МНС I класса на клеточной поверхности эмбриона (І триместр), распознавание которых, как правило, приводит к процессам иммунного отторжения. В силу этого факта ХГ считается одним из основных факторов, формирующих иммунную толерантность во время беременности $[19,196]$.

АФП - это гликопротеин, синтезируемый в фетальной печени. В норме АФП может обнаруживаться в сыворотке эмбриона, начиная с 4-й недели беременности. Его концентрация достигает пика между 12-й и 16-й неделями и затем постепенно снижается вплоть до рождения. Так как АФП проникает через плаценту, он может обнаруживаться в довольно высокой концентрации в сыворотке крови матери, достигая максимума между 32-й и 36-й неделями беременности. Уровень АФП служит важным показателем при мониторинге антенатального периода. Экспериментальные исследования свидетельствуют об иммуносупрессорной активности этого белка [10, 376].

ТБГ - онкофетальный белок, продуцируемый клетками цито- и синцитиотрофобласта во время беременности. В динамике беременности уровень ТБГ постепенно растет и достигает значений 200-400 мкг/мл К III триместру, он становится доминантным белком в сыворотке беременных. В то же время в сыворотке крови плода его уровень не превышает 1-2 мг/л [6, 240].

\section{Т-клетки иммунной памяти}

Известно, что физиологически протекающая беременность сопровождается изменениями, направленными на формирование иммунной толерантности к полуалогенному эмбриону. Одним из наиболее значимых механизмов формирования иммунной толерантности является супрессия Т-клеточной памяти в условиях постоянного воздействия антигенов эмбрионального происхождения [3, 79-82].

В последние годы было показано, что уровень функциональной активности Т-клеток, определяется стадией 
их дифференцировки, характеризующихся различной экспрессией ряда функциональных и адгезионных молекул [18, 745-763]. В литературе имеются единичные работы по дифференцировке Т-клеток памяти при неосложненной беременности, а данные о функциональной активности Т-клеток памяти под воздействием белков зоны беременности отсутствуют. В то же время очевидно, что при неосложненной беременности в периферической крови действуют факторы, приводящие к снижению активности циркулирующего пула Т-клеток памяти, способных к осуществлению антиген-специфических цитотоксических реакций адаптивного иммунитета в отношении антигенов эмбрионального происхождения.

Дифференцировка Т-клеток затрагивает состав внеклеточного домена CD45: в наивных клетках это полная комплектация (CD45RA, 220 кДа), по мере антигензависимой дифференцировки ряд доменов теряется, а продукт конечной модификации обозначают как CD45RO (180 кДа). Т-лимфоциты, экспрессирующие CD45RA ${ }^{+}$, позиционируются как наивные Т-клетки, а экспрессирующие $\mathrm{CD}_{45 \mathrm{RO}^{+}}$- как «примированные» Т-клетки памяти [2, 947-964].

Наивные Т-клетки, экспрессирующие высокомолекулярные изоформы CD45, имеют высокую фосфатазную активность и поддерживают Т-клеточный рецептор (TCR) в примированном состоянии для распознавания антигена $[17,425-437]$.
Процесс активации наивных клеток довольно сложен и требует вовлечения TCR и костимулирующих молекул (CD28 и др.). Переход к низкомолекулярным изоформам - CD45RO при активации Т-клеток снижает фосфатазную активность рецептора CD45 и, как полагают, способствует ослаблению Т-клеточной сигнализации $[15,145-155]$. В свою очередь, быстрый и усиленный ответ $\mathrm{CD}^{4} 5 \mathrm{RO}^{+}$клеток памяти на специфический антиген является их важнейшим функциональным отличием от их «наивных» предшественников.

Альтернативный сплайсинг является одним из важнейших механизмов регуляции генной активности клеток иммунной системы. Важность регуляции альтернативного сплайсинга у человека демонстрируется геном Ptprc, кодирующим лейкоцитарный рецептор $\mathrm{CD} 45$, сопряженный с функциональной активностью Т-клеток человека [20, 231-238]. С помощью механизма альтернативного сплайсинга синтезируется восемь различных изоформ молекулы CD45, пять из которых присутствуют на лимфоцитах (R0, RA, RB, RBC и $\mathrm{RABC}$ изоформы) и определяют этапы их дифференцировки [12; 14, 859-867]. После активации Т-клеток пропуск вариабельных экзонов CD45 приводит к гомодимеризации рецептора на клеточной поверхности и образованию неактивной формы протеинфосфатазы со снижением сигнализации через TCR. Однако факторы, регу-
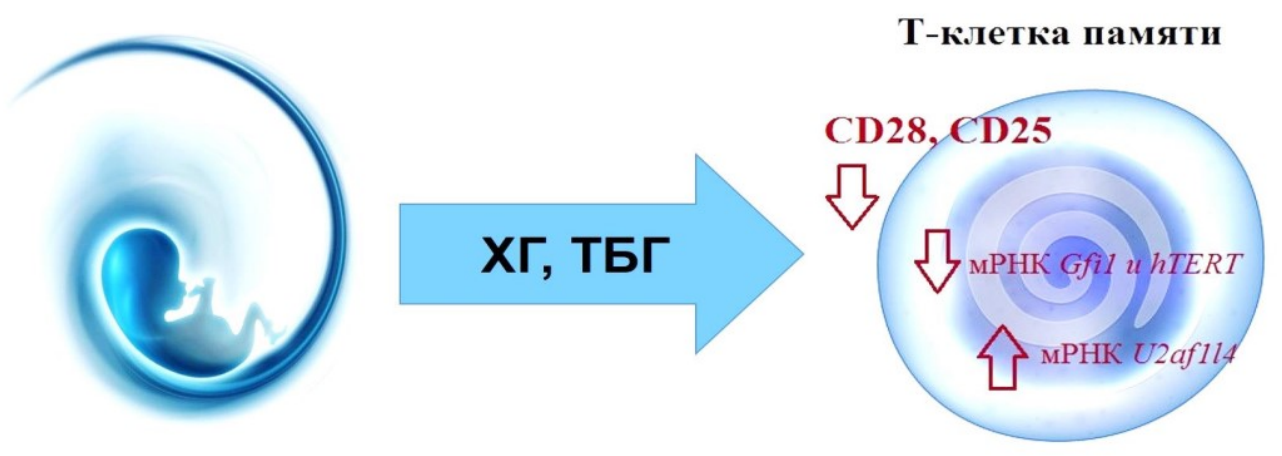

Рис. Ключевые эффекты ХГ и ТБГ на функичинальную активность Т-клеток иммунной памяти 
лирующие экспрессию генов на уровне альтернативного сплайсинга, практически не изучены, за исключением единичных работ $[4,656 ; 9,92-98 ; 11,180-186]$.

\section{Основные результаты}

Изучена роль ХГ, АФП и ТБГ в регуляции процессов, определяющих дифференцировку и созревание наивных Т-клеток в Т-клетки памяти.

Показано, что ХГ в концентрациях, соответствующих физиологической беременности (10 и $100 \mathrm{ME} / \mathrm{Mл),} \mathrm{угнетал} \mathrm{экс-}$ прессию активационных маркеров CD28 и CD25 наивными $\left(\mathrm{CD}_{\left.45 \mathrm{RA}^{+}\right)}\right.$T-клетками и Т-клетками памяти $\left(\mathrm{CD} 45 \mathrm{R} 0^{+}\right)$, не влияя на экспрессию маркера пролиферации CD71. Установлено, что процессы дифференцировки наивных (CD45RA ${ }^{+}$) T-клеток и Т-клеток памяти $\left(\mathrm{CD} 45 \mathrm{R} 0^{+}\right)$под воздействием ХГ осуществляются за счет изменения экспрессии генов - U2afll4, Gfil и hTERT, регулирующих альтернативный сплайсинг гена Ptprc (кодирующего молекулу CD45). Так, ХГ снижал экспрессии мРНК генов Gfil и hTERT, но повышал экспрессию мРНК гена U2afll4. Установлено, что ХГ стимулирует продукцию ИЛ-2 изолированными CD45R0 и CD45RA ${ }^{+}$-лимфоцитами [21, 33-8].

Аутентичный нативный ТБГ человека получали авторским методом [8]. Установлено, что ТБГ $(1,10$ мкг/мл) снижал пролиферативную активность наивных Тклеток (CD45RA $\left.{ }^{+}\right)$, одновременно угнетая экспрессию мРНК гена $h T E R T$ этими клетками. Помимо этого, ТБГ модулировал экспрессию мРНК генов U2af1l4, Gfil и $h n R N P L L$, регулирующих альтернативный сплайсинг гена Ptprc (кодирующего молекулу CD45) наивными Т-клетками. Показано, что ТБГ снижал экспрессию мРНК генов Gfil и $h n R N P L L$, но повышал экспрессию мРНК гена U2af1l4. При изучении эффектов ТБГ на уровне Т-клеток памяти $\left(\mathrm{CD} 45 \mathrm{R} 0^{+}\right)$, установлено, что белок угнетал экспрессию ими маркера активации CD25. Эффекты ТБГ на исследуемые гены Т-клеток памяти были аналогичны - белок снижал экспрессию
мРНК генов Gfil и $h n R N P L L$, но повышал экспрессию мРНК гена U2af1l4. Одновременно ТБГ стимулировал аутокринную продукцию ИЛ-2 как наивными Т-клетками, так и Т-клетками памяти и подавлял экспрессию маркера пролиферативной активности $h T E R T$ исследуемыми субпопуляциями [7, 49-58].

Установлено, что на уровне наивных T-клеток АФП угнетал экспрессию CD28, но повышал экспрессию CD25 (100 ME/мл), а на уровне Т-клеток иммунной памяти АФП угнетал только экспрессию CD25 (50, 100 ME/мл). Не выявлено эффектов АФП на пролиферативный статус исследуемых субпопуляций лимфоцитов, а также на экспрессию ими маркера пролиферации CD71. Внесение АФП (100 МЕ/мл) приводило к повышению уровня ИЛ-2 в супернатантах культур наивных Т-клеток, однако не влияло на уровень ИЛ-2, продуцируемый Т-клетками памяти. Таким образом, АФП угнетал экспрессию CD28 наивными Т-клетками, в то же время, повышая экспрессию CD25 и продукцию ИЛ-2, а на уровне Т-клеток иммунной памяти эффекты АФП затрагивали только снижение экспрессии CD25 [1, 454-458]. Таким образом, впервые показаны модулирующие эффекты ХГ, ТБГ и АФП в отношении дифференцировки и функциональной активности Т-клеток иммунной памяти.

\section{Заключение}

По работам российских коллег мы знаем, что одним из наиболее значимых механизмов формирования иммунной толерантности является супрессия Т-клеточной памяти в условиях постоянного воздействия антигенов эмбрионального происхождения. В исследовании 2017 года эти авторы предполагают, что при неосложненной беременности на системном уровне в периферической крови действуют факторы, препятствующие проявлению «иммунологической памяти» материнских клеток в отношении плода и блокирующие формирование пула клеток памяти, а при преждевременном пре- 
рывании беременности эта защита нарушена [5, 425-426]. Однако, какую роль играют при этом белки, ассоциированные с беременностью, было не ясно. Именно наши исследования, осуществленные в рамках данного проекта, позволили прояснить эти моменты. Нами впервые показано, что ХГ, АФП и ТБГ участвуют в регуляции дифференцировки наивных Т-клеток-предшественниц в Т-клетки памяти в процессе формирования иммунного ответа в контексте беременности.

Одновременно с реализацией нашего проекта в 2017 г. Т.Е. Keiffer и соавт. показали, что физиологическая беременность не влияет на количество периферических $\mathrm{CD} 8^{+}$-лимфоцитов памяти $\left(\mathrm{CD} 45 \mathrm{R0}^{+} \mathrm{CD} 8^{+}\right)$, но существенно регулирует функции $\mathrm{CD} 4^{+}$-лимфоцитов памяти. В частности, во время беременности достоверно повышается количество так называемых эффекторных Т-клеток памяти $\left(\mathrm{CD} 45 \mathrm{R}^{+} \mathrm{CD}^{+} \mathrm{CCR}^{-}\right)$, а спустя $18 \mathrm{мес.}$ после родов показано повышение количества эффекторных (CD45R0 $\left.{ }^{+} \mathrm{CD}^{+} \mathrm{CCR}^{-}\right)$ и центральных Т-клеток памяти $\left(\mathrm{CD} 45 \mathrm{R}^{+} \mathrm{CD}^{+} \mathrm{CCR}^{+}\right)$[16, 1-8]. Авторы считают, что гипотеза о том, что во время беременности генерируются долгоживущие Т-клетки памяти, специфичные к фетоплацентарным антигенам, подтверждается этими исследованиями.

Мы предполагаем, что белки и гормоны, ассоциированные с беременно- стью, служат одним из факторов, не позволяющих сформироваться и реализоваться иммунному ответу на фетоплацентарные антигены. Более того, в нашей работе эффекты фетоплацентарных белков также были сфокусированы на $\mathrm{CD} 4^{+}$-клетках. Мы также впервые продемонстрировали, что белки, ассоциированные с беременностью, принимают непосредственное участие в дифференцировке и созревании наивных Т-клеток памяти посредством регуляции альтернативного сплайсинга гена Ptprc, что, в конечном итоге, может определить исход беременности.

Таким образом, в рамках данного проекта нами показана роль ХГ, АФП и ТБГ в регуляции Т-клеточной памяти. В целом, на основе полученных данных можно сформулировать концепцию разработки фармакологических препаратов, обладающих иммунорегуляторным эффектом и контролирующих Т-клеточную иммунную память. Концептуально, что фетоплацентарные белки подавляют дифференцировку наивных Т-клеток в Т-клетки памяти, тем самым способствуя становлению иммунной толерантности к полуаллогенному плоду. Препараты на основе фетоплацентарных белков (рекомбинантные формы или их пептидные фрагменты) могут быть использованы при лечении посттрансплантационных осложнений, а также при терапии аутоиммунных заболеваний.

\section{Библиографический список}

1. Заморина С.А., Литвинова Л.С., Юрова К.А., Хазиахматова О.Г., Тимганова В.П., Бочкова М.С., Храмиов П.В., Раев М.Б., Черешнев В.А. Роль альфа-фетопротеина в регуляции пролиферации и функциональной активности наивных Т-клеток и Т-клеток иммунной памяти // Бюллетень экспериментальной биологии и медицины. - 2019. - Т. 167. - № 4. - С. 454-458.

2. Кудрявцев И.В. Т-клетки памяти: основные популяции и стадии диференцировки // Российский иммунологический журнал. - 2014. - 8(4). - Р. 947-964.

3. Кудряшова А.В., Кадырова Л.В. Дифференцировка $\mathrm{CD}^{+}$клеток памяти при беременности // Российский иммунологический журнал. - 2014. - Т. 8(17). - № 1. - С. 79-82.

4. Литвинова Л.С., Мазунин И.О., Гуцุол А.А., Сохоневич Н.А., Хазиахматова О.Г., Кофанова К.А. Дозозависимые эффекты стероидных гормонов на экспрессию генов GF11 и U2AF1L4 в T-лимфоцитах разной степени дифференцировки // Молекулярная биология. - 2013. - Т. 47. - № 4. - 656 с.

5. Мишарина Л.В., Сотникова Н.Ю., Кудряшова А.В., Васин И.А., Борзова Н.Ю. Феномен иммунологической памяти при беременности // Российский иммунологический журнал. - 2017. T. 11(20). - № 3. - C. 425-426.

6. Посисеева Л.В., Назаров С.Б., Татаринов Ю.С. Трофобласт-специфический бета-гликопротеин в акушерстве и гинекологии. - Иваново: ОАО «Издательство Иваново», 2004. - 240 с. 
7. Раев М.Б. Литвинова Л.С., Юрова К.А., Хазиахматова О.Г., Тимганова В.П., Бочкова М.С., Храмиов

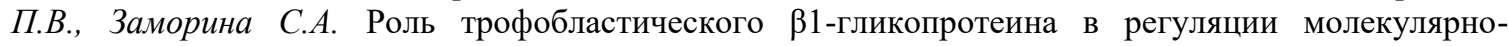
генетических механизмов дифференцирвки Т-клеток иммунной памяти // Медицинская иммунология. -2019 . - Т. 21. - № 1. - С. 49-58.

8. Раев М.Б. Способ выделения и очистки трофобластического $\beta-1$-гликопротеина. Патент РФ № 2367449 от 20.09 .2009 г.

9. Тодосенко Н.М., Юрова К.А., Хазиахматова О.Г., Литвинова Л.С. Влияние метилпреднизолона на поздние этапы дифференцировки $\mathrm{CD} 4^{+}$Т-клеток памяти при ревматоидном артрите исследование in vitro // Физиология человека. - 2019. - Т. 45. - № 3. - С. 92-98.

10. Черешнев В.А., Родионов С.Ю., Черкасов В.А., Малютина Н.Н., Орлов О.А. Альфа-фетопротеин. Екатеринбург: УрО РАН, Издательско-полиграфический комплекс «Звезда», 2004. - 376 с.

11. Юрова К.А., Сохоневич Н.А., Хазиахматова О.Г., Литвинова Л.С. Цитокинопосредованная регуляция экспрессии генов Gfil и U2afll4 активированными Т-клетками с разным дифференцировочным статусом in vitro // Биомедицинская химия. - 2016. - Т. 62. - № 2. - С. 180-186.

12. Butte J.M., Lee J.S., Jesneck J. CD28 costimulation regulates genome-wide effects on alternative splicing // PLOS One. - 2012. - Vol. 7. - № 6. e40032. DOI: 10.1371/journal.pone.0040032.

13. Dong $M$. [et al.] The effect of trophoblasts on $\mathrm{T}$ lymphocytes: possible regulatory effector molecules-a proteomic analysis // Cell Physiol. Biochem. - 2008. - Vol. 21. - № 5-6. - P. 463-472.

14. Heyd F., ten Dam G., Moroy T. Auxiliary splice factor U2AF26 and transcription factor Gfil cooperate directly in regulating CD45 alternative splicing // Nat. Immunol. - 2006. - Vol. 7. - № 8. - P. 859-867.

15. Holmes N. CD45: all is not yet crystal clear // Immunology. - 2006. - Vol. 117(2). - P.145-155.

16. Kieffer T.E., Faas M.M., Scherjon S.A., Prins J.R. Pregnancy persistently affects memory T cell populations // J. Reprod. Immunol. - 2016. - Vol. 119. - P. 1-8.

17. McNeill L., Salmond R.J., Cooper J.C., Carret C.K., Cassady-Cain R.L., Roche-Molina M., Tandon P., Holmes N., Alexander D.R. The differential regulation of Lck kinase phosphorylation sites by CD45 is critical for T cell receptor signaling responses // Immunity. - 2007. - Vol. 27. - № 3. - P. 425-437.

\title{
PREGNANCY-ASSOCIATED PROTEINS AND THEIR ROLE IN THE REGULATION OF T-IMMUNE MEMORY CELL DIFFERENTATION
}

\author{
S.A. Zamorina ${ }^{1}$, V.P. Timganova ${ }^{1}$, M.S. Bochkova ${ }^{1}$, L.S. Litvinova ${ }^{2}$, K.A. Yurova ${ }^{2}$, \\ O.G. Khaziahmatova ${ }^{2}$, P.V. Khramtsov ${ }^{1,2}$, S.V. Kochurova ${ }^{1}$, M.B. Rayev ${ }^{1}$ \\ ${ }^{I}$ Institute of Ecology and Genetics of Microorganisms UB RAS \\ ${ }^{2}$ Immanuel Kant Baltic Federal University
}

The role of chorionic gonadotropin (CG), alpha-fetoprotein (AFP) and pregnancy-specific $\beta$-1-glycoprotein (PSG) in the regulation of the processes determining the differentiation and maturation of naive T-cells into memory T-cells has been studied. It has been established that CG, AFP and PSG have a predominantly suppressing effect on the expression of CD28 and CD25 activation markers by naive T-cells $\left(\mathrm{CD}^{2} 5 \mathrm{RA}^{+}\right)$and memory $\mathrm{T}$-cells $\left(\mathrm{CD} 45 \mathrm{R} 0^{+}\right)$, virtually without affecting the expression of CD71 proliferation marker. It has been established that the differentiation processes of naive T-cells and memory T-cells, under the influence of CG, AFP and PSG, are carried out with changing the expression of the - U2af114, Gfil and hTERT genes, which regulate the alternative splicing of the Ptprc gene (encoding CD45 molecule). At the same time, CG, AFP and PSG stimulated autocrine production of IL-2 with both naive and memory T-cells. Thus, for the first time, the modulating effects of the above-mentioned fetoplacental proteins in relation to the differentiation and functional activity of immune memory T-cells are shown.

Keywords: alpha-fetoprotein, chorionic gonadotropin, trophoblastic b-1-glycoprotein, T-cells of immune memory, pregnancy, CD45. 


\section{Сведения об авторах}

Заморина Светлана Анатольевна, доктор биологических наук, ведущий научный сотрудник лаборатории экологической иммунологии, Институт экологии и генетики микроорганизмов УрО РАН - филиал Пермского федерального исследовательского центра УрО РАН (ИЭГМ УрО РАН), 614081, г. Пермь, ул. Голева, 13; e-mail: mantissa7@mail.ru

Тимганова Валерия Павловна, кандидат биологических наук, младший научный сотрудник лаборатории экологической иммунологии, ИЭГМ УрО РАН; e-mail: timganovavp@gmail.com

Бочкова Мария Станиславовна, кандидат биологических наук, научный сотрудник лаборатории экологической иммунологии ИЭГМ УрО РАН; e-mail: krasnych-m@mail.ru

Литвинова Лариса Сергеевна, доктор медицинских наук, заведующая базовой лабораторией иммунологии и клеточных биотехнологий, Балтийский федеральный университет имени Иммаиуила Канта (БФУ им. И. Канта), 236016, Калининградская обл., г. Калининград, ул. Боткина, 3; e-mail: larisalitvinova@yandex.ru

Хазиахматова Ольга Геннадьевна, кандидат биологических наук, научный сотрудник лаборатории иммунологии и клеточных биотехнологий, БФУ им. И. Канта; e-mail: hazik36@mail.ru

Храмиов Павел Викторович, кандидат биологических наук, младший научный сотрудник лаборатории экологической иммунологии, ИЭГМ УрО РАН; научный сотрудник, БФУ им. И. Канта; e-mail: khramtsovpavel@yandex.ru

Кочурова Софья Вадимовна, инженер лаборатории экологической иммунологии, ИЭГМ УрО РАН; e-mail: kochurova.sofja@yandex.ru

Раев Михаил Борисович, доктор биологических наук, ведущий научный сотрудник лаборатории экологической иммунологии, ИЭГМ УрО РАН; e-mail: mraev@iegm.ru 